\title{
DIFFERENCES IN VISUAL ACUITY, NUTRITIONAL STATUS AND MOTOR FUNCTION IN NEW ELEMENTARY STUDENTS IN RURAL AND URBAN AREA
}

\author{
Dyah Umiyarni Purnamasari ${ }^{1 *}$, Kusnandar ${ }^{2}$, Panuwun Joko Nurcahyo ${ }^{2}$ \\ ${ }^{1}$ Nutrition Program, Faculty of Health Science, Universitas Jenderal Soedirman, Indonesia \\ ${ }^{2}$ Sport Education Program, Faculty of Health Science, Universitas Jenderal Soedirman, Indonesia \\ *E-mail: dyahumiyarni@gmail.com
}

\begin{abstract}
School children in rural and urban areas need attention in terms of education and health. This study was aimed to analyze differences in visual acuity, nutritional status and motor function among school-age children in rural and urban areas. This was an analytic observational with cross-sectional design. As much as 57 students at SD Sokanegara and Kedungbanteng elementary school was recruited by purposive sampling method with inclusion criterias including first grade of elementary school student in healthy condition. Visual acuity data was examined by using Snellen Chart, nutritional status data by anthropometric measurements of body weight and height was calculated using the BMI for age index, while motor function was obtained by Carpenter Motor Ability Test measurements. Data was analyze using the Mann Whitney test. The results showed there were differences in visual acuity $(p=0.001)$ and nutritional status $(p=$ 0.027 ) in rural and urban school children, while motor function did not show any significant difference $(p=0.783)$. It is recommended to increase outdoor activities as a protection against visual acuity.
\end{abstract}

Keywords: school-age children, motoric function, visual acuity, nutritional status

\section{BACKGROUND}

Statistics show that the number of primary school children in Indonesia was quite large, totaling 2,238,923 students spread throughout Indonesia both urban and rural (Kemendikbud, 2019). Therefore, the health conditions of schoolage children need to be considered. This is because school children are vulnerable to various health problems that can have an impact on their learning activities

The role of eye acuity in new school-age children is very important. As much as $80 \%$ of the knowledge is learned by children in through visual information processing. Vision problems can cause unwanted effects in the process of reading and writing, as well as learning achievement. A survey of school-age children in Brazil found that children with low visual acuity as much as $15.5 \%$ had lower learning achievement compared to children with better visual acuity. Eye acuity was also associated with the motor function, cognitive function and language development (Toledo et al., 2010). Basic Health Research Data showed the prevalence of less sharp vision for children aged 6-14 years was $0.8 \%$ in urban areas and $1.1 \%$ in rural areas (Ministry of Health Republic of Indonesia, 2013).

Besided the problem of eye acuity among school-age children, UNICEF Joint WHO and the World Bank in its survey found a total of 51 million (7.5\%) school children in thin condition and 151 million (22.2\%) in short conditions (Stunted)), as for those who overweight (38 million) (5.6\%) (Unicef WHO and World Bank, 2017). Whereas in Indonesia, school-age children who are in thin and very thin conditions were $9.2 \%$; short and very short $23.6 \%$; and $20 \%$ were overweight and obese (Kemenkes RI, 2018).

Both gross and fine motor development of school-age children are need to be trained and developed in order to enable children to gain better achievement both academically and physically. Based on Basic Health Survey (RISKESDAS) (2018), the prevalence of disability in children aged 5-17 years was quite large. A child was said to have a disability if there was difficulty or impairment in motor function that is severe or very severe. The national prevalence of motoric disability among children was $3.3 \%$ in total, including $3.6 \%$ in 
urban areas and 2.9\% in rural areas (Indonesian Ministry of Health, 2018).

The neighborhood environment could affect a person's health. Research by Renaldo and Supriatna (2017) found differences in motor functions in running and throwing among elementary school students in urban and rural areas. Research conducted by Mexitalia et al. (2012) showed there were differences in the nutritional status of school children in rural and urban areas. This study aims to analyze the difference in vision acuity, nutritional status and motor function in school-age children in rural and urban areas

\section{METHODS}

The research method used was an analytic observational research method with cross-sectional study design. This research design was used to study the dynamics of correlation by approaching, observing or collecting data at one time (point time approach). This study was approved by Internal Reviewer Board Faculty of Medicine, Universitas Jendral Soedirman (2911/KEPK/V/2019).

This research was conducted to students at SD Sokanegara I and SD Kedungbanteng I in MarchMay 2019. The sampling technique used purposive sampling, with the inclusion criteria including first-grade students with healthy condition. The number of samples at SD Sokanegara was 24 students and at Kedungbanteng Elementary School were 34 students, bringing the total to 57 students. Measurement of visual acuity was performed using a Snellen Card conducted by a health worker, a certified nurse. Normal vision was defines as $20 / 20$ in feet or $6 / 6$ in meters. Visus $6 / 6$ was the normal vision threshold where a person can undergo activities quite well in school (Suarya et al, 2016). The lower visual acuity indicates lower eye acuity.

Nutritional status is a picture of a balance between intake and body needs. Weighing was done using digital scales (merc: Camry) with accuracy of 0.001 . Height measurements was conducted using the stature meter (brand: GEA) with the accuracy of $0.1 \mathrm{~mm}$. Furthermore, nutritional status was determined by Body Mass Index for Age Z-Score. Nutritional status is considered normal if it is within the range of -2 to $+1 \mathrm{SD}$. The subjects were belongs to thin group if BMI/A <-2 SD and classified as overweight if $\mathrm{BMI} / \mathrm{A}>+2 \mathrm{SD}$. The anthropometric index has been approved by the Indonesian Ministry of Health as a tools to determine the nutritional status among children. The higher BMI/A score indicates the potential for overweight (Anthropometry Standard Assessment of Child Nutrition Status, 2010).

Motor function is the development of a person's ability and volition to maximize his work. Motor function was measured using Carpenter Motor Ability. The measurement method is appropriate to be used to measure gross motor skills in lower grades (1-3) of elementary school children. The determination used 2 measurement techniques consisted of Standing Board Jump to measure leg muscle strength; and Shot Put to measure arm muscle strength. In this study we measured the length of the jump using Standing Board Jump, which is a long jump without the start using a $2 \times 2$ meter sandbox. Moreover, we also assessed distance of repulsion form Shot Put test using $2 \mathrm{~kg}$ bullet. Measurement was carried out 3 times, then the results were averaged. Overall score was determined by following formulation (Nurhasan, 2000):

- Male : distance of Standing Board Jump + 2.5 (Shot Put distance) +0.05 (body weight)

- Female: distance of Standing Board Jump + 1.5 (Shot Put distance) +0.05 (body weight)

Measurement of motor function was carried out by school sports teachers. Collected datas were analyzed using Mann Whitney test with significance level of $p$ value $<0.05$.

\section{RESULT AND DISCUSSION}

All samples were first-grade students at SD Kedungbanteng I (rural) and SD Sokanegara I (urban). The average age of the sample was 6 years 9 months. The youngest age was 6 years 7 months, whole the oldest was 8 years 8 months. A total of $56.1 \%$ were male and $43.9 \%$ were female.

Visual acuity among school-age children in rural areas was higher $(90.9 \%)$ than urban areas students $(83.3 \%)$. Moreover, urban school had higher proportion of obese student (29.2\%) compared to rural school (15.1\%). BMI/A scores among rural school-age children was lower than in 
Table 1. Categories of Visual Acuity, Nutritional Status and Motor Function among School-Age Children in Rural and Urban Areas

\begin{tabular}{lcccc}
\hline \multirow{2}{*}{ Variable } & \multicolumn{2}{c}{ Urban } & \multicolumn{2}{c}{ Rural } \\
\cline { 2 - 5 } & $\mathbf{n}$ & $\mathbf{\%}$ & $\mathbf{n}$ & $\%$ \\
\hline Visual Acuity & & & & \\
Sharp & 20 & 83.3 & 30 & 90.9 \\
Less sharp & 4 & 16.7 & 3 & 9.1 \\
Nutritional Status & & & & \\
Overweight & 7 & 29.2 & 5 & 15.1 \\
Normal & 15 & 62.5 & 26 & 78.8 \\
Underweight & 2 & 8.3 & 2 & 6.1 \\
Motor Function & & & & \\
Poor & 11 & 47.8 & 13 & 39.4 \\
Moderate & 3 & 13.1 & 5 & 15.2 \\
Good & 10 & 43.1 & 15 & 45.4 \\
\hline
\end{tabular}

urban areas. Meanwhile, the percentage of student with good motor function was bigger in rural than urban area (45.4 vs 43.1\%) (Table 1).

A significant differences in visual activity was found between urban and rural students $(p=0.001)$. Up to $90.1 \%$ urban students had better visual acuity, while in urban area, only $83.3 \%$ students had good vision (Table 2). This result was in line with research conducted by $\mathrm{Xu}$ et al. (2005) in China which showed children in rural areas had better eye acuity than in urban areas.

There are 3 things that become the main factors causing the decrease in visual acuity, namely the sharpness of retinal focus, health and retina function, as well as the brain sensitivity for visual interpretation (Suarya et al., 2016). The sharpness of the eye could be affected by screen time. Screen time is the time used to do screen-based activities or activities in front of the electronic media screen such as watching television or video, using computer, or playing video games.
This causes someone prone to eye problems. Eye disorders are caused by radiation waves from monitor screen that would be captured by cornea, then transmitted to the lens. School-age children who were exposed to electronic media for a long time had weak ciliary muscles. This would affect the lens to become convex because they always see objects in close distance. Furthermore, they became less sensitive to distant objects, and this might causes visual disturbances (James, 2006).

Children who spend 2 or more hours in front of an electronic screen had lower eye acuity (Porotu'o, Joseph, and Sondakh, 2015). Children in urban areas had higher screen time than in rural areas. According to Yang et al., (2016), an increase of outdoor activity time was important protection factor against visual impairment. This is because the long distance vision in the outdoor area would make eye accommodation become relaxed and reduce blur when looking at close objects. In addition, sunlight in the outdoor area causes constriction of the pupils which results in greater depth of field and less blurred images.

We also found significant differences in the nutritional status among school children in rural and urban areas $(p=0.027)$. This finding was in line with a research conducted by Dian et al. (2015) which also discovered differences in nutritional status in school children in urban and rural areas.

The proportion of obese student was higher in urban (29.2\%) than rural school (15.1\%). According to WHO (2013), a case of obesity throughout the world have been increasing and quite alarming. As many as 42 million children worldwide were overweight, whereas 31 million of them were in developing countries. In 2008, Collins et al. conducted a research on determinant

Table 2. Characteristics of visual acuity, nutrition status and motor function of school-age children in rural and urban areas

\begin{tabular}{lcccc}
\hline \multicolumn{1}{c}{ Variable } & Area & Mean \pm SD & Min-Max & Mean Rank value \\
\hline Visual Acuity & Urban & $0.85 \pm 0.29$ & $0.25-1.33$ & 20.71 \\
& Rural & $1,12 \pm 0.26$ & $0.60-1.84$ & 35.03 \\
BMI/A & Urban & $0.38 \pm 1.71$ & $-2.24-4.68$ & 34.69 \\
& Rural & $-0.42 \pm 1.48$ & $-2.38-4.63$ & 24.86 \\
Motoric Score & Urban & $581.01 \pm 221.84$ & $300.84-933.80$ & 28.29 \\
& Rural & $583.94 \pm 187.30$ & $313.84-894.98$ & 29.52 \\
\hline
\end{tabular}


of obesity among school-age children in Indonesia. The results proven that driven factors related to obesity comprised family income, screen time, transportation mode, and fast food consumption. Children in urban areas tend to had higher family income compared to rural children. In addition, they often went to school using motor vehicles and easier access to fast food. Rey-Lopez et al. (2008) examined the relationship of sedentary behavior in children such as playing digital games, computers and watching television with the incidence of obesity in children. The amount of time spent watching television could interfere children's growth and development because it caused children to be less active. Thus, the body fat was accumulated easily, lead it to obesity. Sedentary behavior in school-age children need to be concerned. Study by Wulandari et al. (2016) confirmed a shift of activity pattern among schoolage children in rural area of Bali, Indonesia. They began to do sedentary activities after school such as watching television and playing gadgets that resulted in an increase of overweight cases.

In this study there were no differences in motor function between school children in rural and urban areas $(\mathrm{p}=0.783)$. According to Endang (2007), gross motor skills, namely the ability to run a muscle while doing activities using large muscles such as non-locomotor and locomotor. Non locomotor movements are movements that do not move the body, such as folding, pushing, pulling, bending, and others. Whereas locomotor motion is movement that moves to a different location. Examples of these movements are throwing, catching, kicking, and dribbling.

There were many factors that affect a child's gross motor function including gender, weight, neural maturity, developmental sequence, nutritional status, exercise, motivation, experience, and environment (Kamtini, 2014). In this study, there were no differences in motor function of school children in rural and urban areas which might be influenced by environmental conditions and the neurological maturity of children. Anindhita (2017) proved that there was a correlation between age and the maturity of the body's function and gross motor abilities. Increasing the age of a child would be followed with increament of motor function abilities. In this study, all subjects were taken from first-grade with similar age, so their motor skills have not yet developed and might not significantly different.

\section{CONCLUSION}

In this study, we found differences in visual acuity and nutritional status of children, but there was no difference in motor function of children between rural and urban elementary schools. From this finding, it can be suggested to maintain the visual acuity of school children by increasing outdoor activities among school-age children in urban areas. This activity can broaden visibility and can reduce sedentary activity which is the cause of obesity in children so that it also affects the improvement of nutritional status.

\section{REFERENCES}

Anindhita. (2017). Faktor-Faktor yang Berhubungan dengan Motorik Kasar pada Anak Toddlers. Jurnal Keperawatan Muhammadiyah, 2(2). Retrieved from http://journal.um-surabaya. ac.id/index.php/JKM/article/view/924

Collins, A.E., Pakiz, B., \& Rock, C.L. (2008). Factors associated with obesity in Indonesian adolescents. International Journal of Pediatric Obesity, 3(1), 58-64. Retrieved from https://www.tandfonline. com/doi/abs/10.1080/17477160701520132

Dian, R, Purnamasari, D.U., \& Kusnandar, K. (2015). Perbedaan status gizi dan tingkat kesegaran jasmani pada anak sekolah dasar perdesaan dan perkotaan. Kesmas Indonesia, 7(03), 237-243. Retrieved from http://jos. unsoed.ac.id/index.php/kesmasindo/article/ view/135

Endang. (2007). Perkembangan Motorik. Yogyakarta: Universitas Negeri Yogyakarta.

James. (2006). Oftamology (edisi sembilan). Berlin: EMS Publisher.

Kamtini. (2014). Motorik Kasar Anak Usia Dini. Jakarta: Media Persada.

Kemendikbud. (2019). Jumlah Siswa Menurut Tingkat Propinsi. Retrieved from http://statistik. data.kemdikbud.go.id/

Kemenkes RI. (2010). Standar Antropometri Penilaian Status Gizi Anak. Jakarta: Kemenkes RI.

Kemenkes RI. (2013). Riset Kesehatan Dasar 2013. Jakarta: Kemenkes RI

Kemenkes RI. (2018). Laporan Riset Kesehatan 
Dasar 2018. Jakarta: Kemenkes RI

Mexitalia, M., Sellina, H., Anam, M. S., Yoshimura, A., Yamauchi, T., Nurkukuh, N., \& Hariyana, B. (2012). Perbedaan status gizi, kesegaran jasmani, dan kualitas hidup anak sekolah di pedesaan dan perkotaan. Jurnal Gizi Klinik Indonesia, 8(4), 182-187. Retrieved from https://journal.ugm. ac.id/jgki/article/view/18216

Nurhasan. (2000). Tes dan Pengukuran Pendidikan Olahraga. Bandung: Universitas Pendidikan Indonesia.

Porotu'o, L. I., Joseph, W. B. S., \& Sondakh, R.C. (2015). Faktor-Faktor yang Berhubungan Dengan Ketajaman Penglihatan Pada Pelajar Sekolah Dasar Katolik Santa Theresia 02 Kota Manado. Kesehatan Masyarakat, 4(1). Retrieved from https://ejournal.unsrat.ac.id/ index.php/kesmas/article/view/7237

Renaldo, I. M., \& Supriatna, S. (2017). perbedaan kemampuan motorik antara siswa SD Siman 2 di kabupaten kediri dan siswa SD Singonegaran 2 di kota kediri. Indonesia Performance Journal, 1(2), 98-105. Retrieved from http://journal2. um.ac.id/index.php/jko/article/view/2465

Rey-Lopez, J. P., Vicente-Rodríguez, G., Biosca, M., \& Moreno, L. A. (2008). Sedentary behaviour and obesity development in children and adolescents. Nutrition, Metabolism and Cardiovascular Diseases, 18(3), 242-251. Retrieved from https://www.sciencedirect.com/ science/article/abs/pii/S093947530700169X
Suarya, L. M. K., Lestari, M. D., Tirtayasa, K., Purnawati, S., \& Dinata, I. M.K. (2016). Biopsikologi. Denpasar, Bali: Program Studi Psikologi Fakultas Kedokteran Universitas Udayana.

Toledo, C. C., Paiva, A. P., Camilo, G. B., Maior, M. R., Leite, I. C., \& Guerra, M. R. (2010). Early detection of visual impairment and its relation to academic performance. Revista Da Associacao Medica Brasileira, 56(4), 415-419.

UNICEF WHO dan World Bank. (2017). Level and Trend in Child Nutrition.New York: UNICEF WHO

WHO. (2013). Childhood Overweight and Obesity.

Wulandari, N.W.M., Muniroh, L., \& Nindya, T.S. (2016). Asupan energi dan aktivitas fisik berhubungan dengan z-score imt/u anak sekolah dasar di daerah perdesaan. Media Gizi Indonesia, 10(1), 51-56. Retrieved from https://e-journal. unair.ac.id/MGI/article/view/3126/2283

Xu, L., Li, J., Cui, T., Hu, A., Zheng, Y., Li, Y., Jonas, J.B. (2005). Visual acuity in northern China in an urban and rural population: the Beijing Eye Study. British Journal of Ophthalmology, 89(9), 1089-1093. Retrieved from https://bjo.bmj. com/content/89/9/1089.short

Yang, F., Yang, C., Liu, Y., Peng, S., Liu, B., Gao, X., \& Tan, X. (2016). Associations between Body Mass Index and Visual Impairment of School Students in Central China. International Journal Environmental Research, 13. Retrieved from https://www.mdpi.com/1660-4601/13/10/1024 